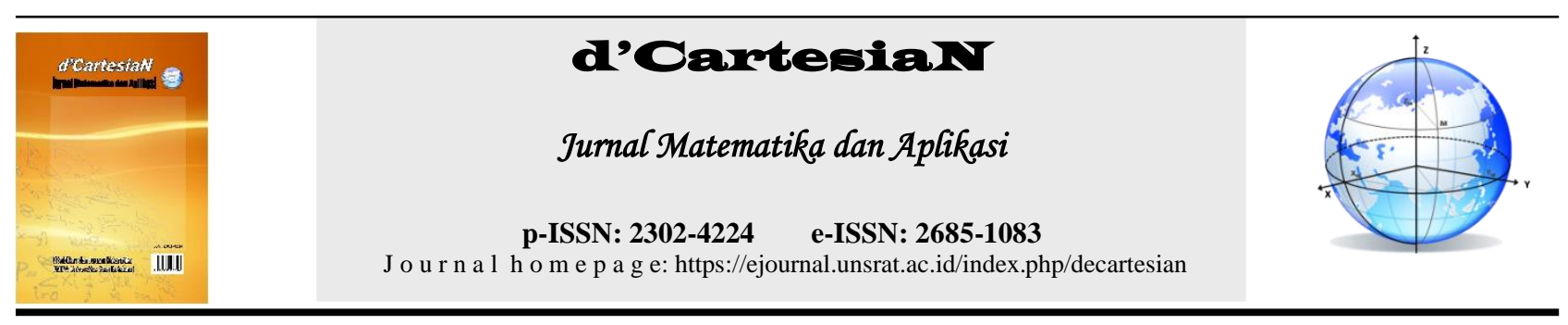

\title{
Analisis Regresi Data Panel Untuk Peramalan Konsumsi Energi Listrik di Sulawesi Utara
}

\author{
Dikky Malvino Maingga ${ }^{1}$, Deiby Tineke Salaki ${ }^{1}$, John Socrates Kekenusa ${ }^{{ }^{*}}$
}

${ }^{1}$ Jurusan Matematika-Fakultas Matematika dan Ilmu Pengetahuan Alam-Universitas Sam Ratulangi Manado, Indonesia ${ }^{*}$ Corressponding author : johnskekenusa@unsrat.ac.id

\begin{abstract}
A B S T R A K
Seiring dengan peningkatan konsumsi energi di Sulawesi Utara, Produk Domestik Regional Bruto (PDRB) juga mengalami peningkatan di setiap sektor. Konsumsi energi dan PDRB merupakan suatu variabel yang tersusun atas beberapa sektor dengan karakteristik yang berbeda-beda, oleh sebab itu penelitian ini menggunakan metode analisis regresi data panel. Tujuan penelitian ini ialah menganalisis pengaruh dari PDRB terhadap konsumsi energi listrik di Sulawesi Utara, untuk masing-masing sektor. Setiap variabel independen pada masing-masing sektor, dilakukan peramalan menggunakan analisis trend. Hasil peramalan tersebut disubstitusikan ke dalam model regresi data panel yang telah diperoleh untuk meramalkan jumlah konsumsi energi listrik di Sulawesi Utara untuk tahun 2019 dan 2020. Data cross section dalam studi ini ialah rumah-tangga, industri, publik, dan bisnis; sedangkan data time series diambil kurun waktu tahun 2010-2018. Hasil penelitian ini menunjukkan bahwa model regresi data panel terbaik menggunakan FEM (Fixed Effect Model) dengan efek individu dengan persamaan regresi data panelnya adalah Konsumsi Energi Listrik ${ }_{i t}=\hat{\beta}_{i}+0,0000437 P D R B_{i t}$. Dimana PDRB dapat menjelaskan konsumsi energi listrik sebesar 97,64\%. Hasil peramalan menunjukkan bahwa konsumsi energi di SULUT pada tahun 2019 dan 2020 meningkat untuk sektor rumah tangga dan publik. Sebaliknya, sektor industri dan bisnis mengalami penurunan pada tahun 2019 dan kembali meningkat pada tahun 2020.
\end{abstract}

\section{A B S T R A C T}

Along with the increase in energy consumption in North Sulawesi, the GRDP has also increased in each of the sectors. The level of prices and the availability of energy needed in the economy will also affect the macroeconomic performance of North Sulawesi. Because energy consumption and GRDP are variables composed of several sectors with different characteristics, therefore this study uses panel data regression analysis method, with the aim to analyze the effect of Gross Regional Domestic Product (GRDP) on energy consumption electricity in North Sulawesi for each sector. Each independent variable in each sector is forecasted using trend analysis and then the forecast results are substituted into a panel data regression model that has been obtained to predict the amount of electricity consumption in North Sulawesi for 2019 and 2020. The results of this study indicate that the best panel data regression model using FEM (Fixed Effect Model) with individual effects with the panel data regression equation is Electric energy consumption ${ }_{i t}=\hat{\beta}_{i}+0,0000437 P D R B_{i t}$. Where the GRDP can explain electrical energy consumption of $97.64 \%$. Forecasting results show that energy consumption in North Sulawesi in 2019 and 2020 increased for the household and public sectors. Conversely, the industrial and business sectors will decline in 2019 and increase again in 2020.

\section{PENDAHULUAN}

Sumber kelistrikan di Provinsi Sulawesi Utara saat ini dipasok oleh pusat-pusat pembangkit meliputi PLTP, PLTU, PLTA/M, dan PLTD HSD dengan total kapasitas terpasang sebesar 384 MW. Beban puncak sistem ini ialah $324 \mathrm{MW}$, namun angka ini akan terus bertambah. Cadangan sumber-sumber ini di bawah 10\% (di bawah cadangan yang wajar), sehingga masih sering terjadi

\section{INFO ARTIKEL}

Diterima : 12 Juli 2020

Diterima setelah revisi : 16 September 2020

Tersedia online : 30 September 2020

\section{Kata Kunci:}

Analisis Trend

Cross Section

Fixed Effect Model

PDRB SULUT

Time Series

\section{ARTICLE INFO}

Accepted : 12 July 2020

Accepted after revision : 16 September 2020

Available online : 30 September 2020

\section{Keywords:}

Trend Analysis

Cross Section

Fixed Effect Model

GRDP SULUT

Time Series pemadaman. Di sisi lain keterbatasan uap panas bumi PLTP Lahendong dan variasi musim, menyebabkan kemampuan PLTA sering kali menurun. Dengan demikian, dianggap perlu untuk melakukan peramalan dan pemodelan konsumsi energi di Sulawesi Utara sebagai bahan acuan untuk menerapkan kebijakan mengenai energi di masa mendatang. Peramalan nilai suatu variabel atau beberapa variabel pada masa yang akan datang sangat diperlukan sebagai dasar atau 
pedoman dalam pembuatan rencana yang menyangkut masa datang [1].

Pada penelitian ini, digunakan analisis regresi data panel untuk mengetahui pengaruh dari pertumbuhan ekonomi (PDRB) terhadap konsumsi energi di Sulawesi Utara. Metode ini digunakan karena konsumsi energi dan pertumbuhan ekonomi merupakan suatu variabel yang tersusun atas beberapa sektor dengan karakteristik yang berbeda-beda.

Regresi data panel memodelkan data gabungan antara data cross-section dan time-series, yang bertujuan untuk mengetahui pengaruh variabel iependen terhadap variabel dependen dalam beberapa sektor yang diamati dari suatu objek penelitian selama periode waktu tertentu. Selain itu, regresi data panel juga digunakan untuk melakukan peramalan variabel dependen untuk setiap sektor. Peramalan variabel dependen dapat dilakukan, jika data dari variabel independen untuk setiap sektor diketahui.

Model terbaik yang diperoleh, akan digunakan untuk memprediksi konsumsi energi di Sulawesi Utara dalam mengantisipasi ketersediaan energi, sehingga proses perekonomian mampu berjalan dengan baik.

\section{TINJAUAN PUSTAKA}

\subsection{Model Regresi Data Panel}

Model umum regresi data panel dinyatakan dalam bentuk persamaan:

$$
\begin{gathered}
Y_{i t}=\beta_{0 i t}+\sum_{k=1}^{K} \beta_{k i t} X_{k i t}+\varepsilon_{i t} \\
i=1,2, \ldots, N, t=1,2, \ldots, T, k=1,2, \ldots, K
\end{gathered}
$$

dimana i menunjukkan banyaknya unit cross-section sejumlah $\mathrm{N}$, dan t menunjukkan banyaknya time-series sejumlah T. $Y_{i t}$ ialah variabel dependen pada unit observasi ke-i dan waktu ke-t. $X_{k i t}$ ialah variabel independen ke-k pada unit observasi ke-i dan waktu ket. $\beta_{\text {kit }}$ adalah slope independen ke-k pada unit observasi ke-I, dan waktu ke-t. $\beta_{0 i t}$ adalah intersep untuk unit observasi ke-i dan waktu ke-t.

\subsection{Struktur Umum Model}

Dalam mengestimasi model regresi data panel, metode yang akan digunakan sangat bergantung pada asumsi yang dibuat mengenai intersep, koefisien regresi, dan galat. Pada dasarnya ada tiga pendekatan untuk meregresi data panel, yaitu: kuadrat terkecil (Pooled Least Square), efek tetap (Fixed Effect Model), dan efek acak (Random Effect Model) [2].

\subsubsection{Pendekatan Kuadrat Terkecil (Pooled Least Square)}

Struktur model ini sering juga disebut dengan Common Effect Model (CEM). Model ini pada dasarnya mengabaikan struktur panel dari data, sehingga diasumsikan bahwa perilaku antar individu sama dalam berbagai kurun waktu. Secara umum, persamaan model Common Effect Model (CEM) ditulis sebagai berikut:

$$
\begin{gathered}
Y_{i t}=\beta_{0}+\sum_{k=1}^{K} \beta_{k} X_{k i t}+\varepsilon_{i t} \\
i=1,2, \ldots, N, t=1,2, \ldots, T, k=1,2, \ldots, K
\end{gathered}
$$

dimana $\beta_{0}$ adalah Intercept bersama untuk semua unit, $\beta_{k}$ adalah slope bersama untuk semua unit, dan $\varepsilon_{i t}$ adalah galat atau komponen error pada unit observasi ke-i dan waktu ke-t.

\subsubsection{Pendekatan Efek Tetap (Fixed Effect Model}

Model FEM dengan efek tetap maksudnya ialah bahwa suatu objek, memiliki konstan yang tetap besarnya untuk berbagai periode waktu. Demikian pula dengan koefisien regresi yang besarnya tetap dari waktu ke waktu (time invariant) [3]. Persamaan model FEM ialah sebagai berikut:

$$
Y_{i t}=\beta_{0 i}+\sum_{k=1}^{K} \beta_{k} X_{k i t}+\varepsilon_{i t}
$$

\subsubsection{Pendekatan Efek Acak (Random Effect Model}

Model ini akan mengestimasi data panel, dimana variabel galat mungkin saling berhubungan antar waktu dan antar individu. Pada REM perbedaan karakteristik individu dan waktu diakomodasikan pada galat dari model, persamaannya ialah [4]:

$$
Y_{i t}=\beta_{0 i t}+\sum_{k=1}^{K} \beta_{k} X_{k i t}+\varepsilon_{i t} ; \quad \varepsilon_{i t}=u_{i}+v_{t}+w_{i t}
$$

\subsection{Pemilihan Model Estimasi Regresi Data Panel \\ 2.3.1. Uji Chow}

Pengujian ini digunakan untuk memilih salah satu model pada regresi data panel, yaitu antara FEM dengan CEM. Hipotesis uji Chow sebagai berikut:

Hipotesis:

$H_{0}: \alpha_{1}=\alpha_{2}=\cdots=\alpha_{n}=0$ (CEM atau efek individu secara keseluruhan tidak berarti)

$H_{1}$ : Minimal ada satu $\alpha_{i} \neq 0 ; i=1,2, \ldots, n$ (FEM atau efek individu berarti).

Statistik uji yang digunakan ialah uji F, yaitu:

$$
F_{\text {hitung }}=\frac{[R R S S-U R S S]}{U R S S} \times \frac{(N T-N-K)}{(N-1)}
$$

dimana $\mathrm{N}$ ialah banyaknya unit cross-section, $\mathrm{T}$ ialah banyaknya data time series, K adalah banyaknya variabel independen. RRSS adalah restricted residual sums of squares yang berasal dari model CEM, sedangkan URSS adalah unrestricted residual sums of squares yang berasal dari model FEM.

Jika nilai $F_{\text {hitung }}>F_{(n-1, n T-n-K)}$ atau $p-$ value $<$ taraf signifikansi, maka tolak hipotesis nol $\left(H_{0}\right)$ yang berarti model FEM yang lebih baik.

\subsubsection{Uji Hausman}

Uji ini digunakan untuk memilih antara REM dengan FEM. Prosedur pengujiannya sebagai berikut [5]:

Hipotesis:

$H_{0}$ : Korelasi $\left(X_{i t}, \varepsilon_{i t}\right)=0$ (Galat tidak berkorelasi dengan regresor lain, atau pilih model REM)

$H_{1}$ : Korelasi $\left(X_{i t}, \varepsilon_{i t}\right) \neq 0$ (Galat berkorelasi dengan regresor lain, atau pilih model FEM).

Statistik uji yang digunakan ialah uji Khi-Kuadrat berdasarkan kriteria Wald, yaitu:

$$
\begin{gathered}
W=\hat{q}^{\prime}\left[\operatorname{var}\left(\hat{q}^{\prime}\right)\right]^{-1} \hat{q} \\
\Leftrightarrow W=\chi^{2}(K) \\
=\left(\hat{\beta}_{F E M}-\hat{\beta}_{R E M}\right)^{\prime}\left[\operatorname{var}\left(\hat{\beta}_{F E M}-\hat{\beta}_{R E M}\right)\right]^{-1}\left(\hat{\beta}_{F E M}-\hat{\beta}_{R E M}\right)
\end{gathered}
$$
dimana $\hat{\beta}_{F E M}$ adalah vektor estimasi slope model FEM, sedangkan $\hat{\beta}_{R E M}$ adalah vektor estimasi slope model REM. Jika nilai $\chi^{2}{ }_{\text {hitung }}>\chi^{2}{ }_{(\alpha, K)}$ atau $p-$ value $<$ taraf signifikansi, maka tolak hipotesis nol $\left(H_{0}\right)$, dan model yang terpilih adalah FEM. 


\subsubsection{Uji Lagrange Multilier}

Uji Lagrange Multiplier (LM) digunakan untuk pengujian random effect yang didasarkan pada nilai galat dari model common effect untuk mengetahui apakah model REM lebih baik daripada model CEM.

$H_{0}: \sigma_{\mu}^{2}=0$ (efek dari individu tidak berarti dalam model, atau pilih CEM),

$H_{1}:{\sigma_{\mu}}^{2} \neq \mathrm{o}$ (efek dari individu berarti dalam model, atau pilih REM).

Nilai statistik uji LM dihitung menggunakan rumus sebagai berikut:

$$
L M=\frac{N T}{2(T-1)}\left[\frac{\sum_{i=1}^{N}\left[\sum_{t=1}^{T} e_{i t}\right]^{2}}{\sum_{i=1}^{N} \sum_{t=1}^{T} e_{i t}^{2}}-1\right]^{2} \sim \chi_{\alpha .1}^{2}
$$

dimana $e_{i t}$ galat model common effects. Uji LM ini didasarkan pada distribusi chi-square dengan derajat bebas sebesar 1. Apabila nilai $L M>\chi_{\alpha .1}^{2}$, maka tolak hipotesis nol $\left(H_{0}\right)$, sehingga model yang terpilih ialah model REM (random effect model) [6].

\subsection{Uji Asumsi Model Regresi Data Panel}

Pada regresi data panel dilakukan beberapa pengujian asumsi, yaitu: normalitas, multikolinieritas, dan heteroskedastisitas.

\subsubsection{Uji Normalitas}

Salah satu cara untuk menguji normalitas galat ialah dengan menggunakan metode Jarque-Bera (JB). Uji JB ini menggunakan perhitungan skewness dan kurtosis [7].

Hipotesis:

$H_{0}$ : Galat berdistribusi normal

$H_{1}$ : Galat tidak berdistribusi normal

Statistik uji:

$$
J B=N\left[\frac{S_{k}{ }^{2}}{6}+\frac{(K-3)^{2}}{24}\right]
$$

dengan $S_{k}$ ialah Skewness (kemencengan), dan $K$ ialah Kurtosis (peruncingan). $H_{0}$ diterima jika $J B<$ $\chi_{(\alpha, 2)}^{2}$, artinya galat berdistribusi normal.

\subsubsection{Uji Multikolinearitas}

Cara mendeteksi adanya multikolineritas dilakukan dengan menghitung Variance Inflation Factor (VIF), degan rumus sebagai berikut:

$$
V I F=\frac{1}{\left(1-R_{k}{ }^{2}\right)}
$$

$R_{k}{ }^{2}$ adalah koefisien determinasi yang diperoleh dari regresi antara peubah bebas ke- $k$ dengan peubah bebas lainnya. Jika VIF > dari 10, maka antar variabel bebas (independent variabel) terjadi persoalan multikolinearitas [8].

\subsubsection{Uji Heteroskedastisitas}

Uji heteroskedastisitas dilakukan untuk menguji apakah dalam sebuah model regresi terjadi ketidaksamaan varians residual dari satu pengamatan ke pengamatan yang lain tetap, maka disebut Heteroskedastisitas [9]. Pengujiannya ialah sebagai berikut [10].

Hipotesis:

$H_{0}: \sigma_{i}^{2}=\sigma^{2} \quad$ (variansi galat tetap atau homoskedastisitas)

$H_{1}$ : minimal ada satu $\sigma_{i}^{2} \neq \sigma^{2}$ (variansi galat berubahubah atau heteroskedastisitas); $i=1,2, \ldots, N$

Statistik uji yang digunakan uji LM yang mengikuti distribusi chi-squared, yaitu:

$$
L M=\frac{T}{2} \sum_{i=1}^{N}\left[\frac{\sigma_{i}^{2}}{\sigma^{2}}-1\right]^{2}
$$

dengan $\sigma_{i}^{2}$ ialah variance residual persamaan ke- $i$ dan $\sigma^{2}$ ialah variance residual persamaan sistem. Jika nilai $\mathrm{LM}>X_{(\alpha, N-1)}^{2}$ atau p-value $<$ taraf signifikan, maka tolak hipotesis nol $\left(H_{0}\right)$, berarti struktur variansi galat bersifat heteroskedastisitas.

\subsection{Pemeriksaan Persamaan Regresi 2.5.1. Uji Simultan (Uji F)}

Uji $\mathrm{F}$ digunakan untuk mengetahui besarnya pengaruh dari seluruh variabel independen secara bersama-sama terhadap variabel dependen. Hipotesis uji $\mathrm{F}$ dituliskan sebagai berikut.

$H_{0}: \beta_{1}=\beta_{2}=\beta_{3}=\beta_{4}=\cdots=\beta_{k}=0$

$H_{1}$ : Paling tidak ada satu $\beta_{i} \neq 0 ; i=1,2, \ldots, K$, dimana $K$ adalah banyaknya variabel bebas.

Statistik Uji:

$$
F_{\text {hitung }}=\frac{R^{2} /(N+K-1)}{\left(1-R^{2}\right) /(N T-N-K)}
$$

Dengan $R^{2}$ adalah koefisien determinasi. $H_{0}$ ditolak jika $F_{\text {hitung }}>F_{(\alpha, N+K-1, N T-N-K) \text {, atau apabila } p-\text { value }}$ $<$ taraf signifikan, artinya bahwa hubungan antara semua variabel independen dan variabel dependen berpengaruh signifikan [11].

\subsubsection{Uji Parsial (Uji t)}

Pengujian hipotesis yang dilakukan secara parsial bertujuan untuk mengetahui pengaruh dan signifikansi dari masing-masing variabel independen terhadap variabel dependen. Hipotesis dalam uji ini alah sebagai berikut:

$H_{0}: \beta_{j}=0$

$H_{1}: \beta_{j} \neq 0 ; \quad j=1,2, \ldots, k(k$ adalah koefisien slope $)$

Statistik uji yang digunakan ialah:

$$
t=\frac{b_{j}}{s b\left(b_{j}\right)}
$$

dengan $b_{j}$ adalah koefisien regresi dan $s b$ adalah simpangan baku. Hipotesis $H_{0}$ ditolak, jika nilai $\left|t_{\text {hitung }}\right|>t_{(\alpha / 2 ; N T-N-K)}$ atau jika $p$-value $<$ taraf signifikan.

\subsubsection{Koefisien Determinasi $\left(R^{2}\right)$}

Koefisien determinasi $\left(R^{2}\right)$, sebagai suatu ukuran yang menginformasikan baik atau tidaknya model regresi yang terestimasi. Nilai $R^{2}$ berkisar dari o sampai 1 , mencerminkan seberapa besar variasi dari variabel dependen $Y$ dapat diterangkan oleh variabel independen $X$. Semakin tinggi nilai $\mathrm{R}^{2}$, semakin baik model yang dibuat [12].

\subsection{Peramalan Menggunakan Model Regresi Data Panel}

Model regresi data panel digunakan sebagai peramalan variabel dependen. Peramalan variabel dependen untuk setiap sektor dapat dilakukan berkisar dari o sampai 1, jika nilai sektor variabel independen selama tahun tersebut diketahui. Dengan demikian, sebelum dilakukan peramalan variabel independen, terlebih dahulu dilakukan peramalan variabel independen untuk beberapa tahun ke depan di setiap sektornya, menggunakan analisis trend: linier, kuadratik, dan eksponensial. Kriteria peramalan terbaik didasarkan pada nilai MAPE, MAD, dan MSD. 


\subsection{Pemilihan Hasil Peramalan}

\subsubsection{MAPE (Mean Absolute Percent Galat)}

MAPE dinyatakan dalam bentuk persentase dan dihitung menggunakan rumus sebagai berikut:

$$
M A P E=\frac{\sum_{i=1}^{N} \sum_{t=1}^{T}\left|\frac{Y_{i t}-\hat{Y}_{i t}}{Y_{i t}}\right|}{n} \times 100(\%)
$$

dimana $Y_{i t}$ ialah nilai data asli pada sektor ke-i waktu ke$\mathrm{t}$, $\hat{Y}_{i t}$ ialah nilai prediksi pada sektor ke-i waktu ke-t, dan $\mathrm{n}$ ialah jumlah observasi atau $\mathrm{N} \times \mathrm{T}$.

\subsubsection{MAD (Mean Absolute Deviation)}

MAD dirumuskan sebagai berikut:

$$
M A D=\frac{\sum_{i=1}^{N} \sum_{t=1}^{T}\left|Y_{i t}-\hat{Y}_{i t}\right|}{n}
$$

dimana $Y_{i t}$ ialah nilai data asli pada sektor ke-i waktu ket, $\hat{Y}_{i t}$ ialah nilai prediksi pada sektor ke-i waktu ke-t, dan $\mathrm{n}$ adalah jumlah observasi atau $\mathrm{N} \times \mathrm{T}$.

\subsubsection{MSD (Mean Squared Deviation)}

MSD adalah ukuran yang lebih sensitif dari kesalahan perkiraan yang luar biasa besar dari MAD. MSD dapat dihitung dengan rumus sebagai berikut:

$$
M S D=\frac{\sum_{i=1}^{N} \sum_{t=1}^{T}\left|Y_{i t}-\hat{Y}_{i t}\right|^{2}}{n}
$$

dimana $Y_{i t}$ ialah nilai data asli pada sektor ke-i waktu ke$\mathrm{t}, \hat{Y}_{i t}$ ialah nilai prediksi pada sektor ke-i waktu ke-t , dan $\mathrm{n}$ ialah jumlah observasi atau $\mathrm{N} \times \mathrm{T}$. [6].

\section{METODE PENELITIAN}

\subsection{Jenis Dan Sumber Data}

Data yang digunakan dalam penelitian ini ialah total konsumsi energi akhir SULUT dan PDRB SULUT atas dasar harga konstan menurut bidang usaha dari tahun 2010 hingga 2018, disusun dalam 4 sektor, yaitu: rumah tangga, industri, publik, dan bisnis. Data konsumsi energi diperoleh dari PT PLN (Persero) Unit Induk Wilayah Suluttenggo, sedangkan untuk data PDRB diperoleh dari Badan Pusat Statistik Sulawesi Utara.

\subsection{Waktu Dan Tempat Penelitian}

Penelitian ini dilaksanakan selama bulan November 2019 sampai Februari 2020, mulai dari penyusunan proposal, pengambilan data, serta pengolahan data. Pengolahan data dilakukan di Laboratorium Komputer Statistik, Fakultas Matematika dan Ilmu Pengetahuan Alam, Universitas Sam Ratulangi Manado.

\subsection{Variabel Penelitian}

Variabel yang digunakan dalam penelitian ini ialah Total konsumsi energi listrik Sulawesi Utara (Giga Wath Hours, Gwh) di 4 sektor yaitu sektor rumah tangga, industri, publik, dan bisnis sebagai variabel dependen (Y); serta Produk Domestik Regional Bruto Sulawesi Utara atas dasar harga konstan (juta rupiah) di 4 sektor tersebut sebagai variabel independen (X).

\subsection{Analisis Data}

Pengolahan data dilakukan dengan menggunakan software Microsoft excel 2016, Minitab 17, dan Eviews 9. Model Regresi Panel dalam penelitian ini ialah:

$$
Y_{i t}=\beta_{0 i t}+\beta_{1 i t} X_{i t}+\varepsilon_{i t}
$$

dengan $i$ ialah indeks untuk rumah tangga, publik, bisnis, dan industri, $t$ untuk waktu dari 2008 sampai 2018, $\beta_{1 i t}$ adalah koefisien kemiringan untuk semua unit, $\beta_{0 i t}$ adalah intersep untuk semua unit, $Y_{i t}$ adalah nilai variabel dependen Konsumsi Energi Listrik untuk cross section ke- $i$ time series ke-t, $X_{i t}$ adalah nilai variabel independen PDRB untuk cross section ke-i time series ke- $t$ dan $\varepsilon_{i t}$ adalah ilai galat cross section ke-i time series ke-t.

Langkah-langkah yang dilakukan untuk menganalisis data ialah sebagai berikut:

1. Menentukan model regresi data panel yang terbaik untuk memodelkan PDRB dengan konsumsi energi di SULUT.

a. Mengestimasi model CEM, model FEM, dan model REM.

b. Menentukan model terbaik melalui Uji Chow, uji LM, dan uji Hausman.

c. Melakukan uji asumsi klasik regresi data panel

d. Pemeriksaan persamaan regresi dengan melakukan uji signifikansi parameter regresi data panel yang meliputi: Uji Serentak (Uji F), Uji Parsial (Uji t), dan menghitung nilai Koefisien Determinasi $\left(\mathrm{R}^{2}\right)$

e. Interpretasi model regresi.

2. Melakukan peramalan untuk variabel dependen berdasarkan model regresi data panel yang telah diperoleh untuk beberapa periode mendatang.

a. Melakukan peramalan untuk masing-masing variabel independen PDRB SULUT untuk masing-masing sektor yang ada, menggunakan analisis trend linear, kuadratik, dan eksponensial.

b. Menentukan hasil peramalan yang terbaik dari ketiga metode berdasarkan nilai MAPE, MAD, dan MSD yang paling kecil.

c. Mensubstitusi hasil peramalan variabel independen PDRB SULUT untuk masingmasing sector, pada masing-masing model regresi data panel yang telah diperoleh untuk mendapatkan hasil peramalan dari variabel dependen konsumsi energi SULUT di setiap sektor.

Setelah peramalan dilakukan, hasil peramalan variabel independen disubstitusi ke dalam persamaan regresi data panel, sehingga diperoleh nilai ramalan untuk variabel dependen.

\section{HASIL DAN PEMBAHASAN}

4.1. Analisis Deskriptif

Data variabel PDRB dan konsumsi energi SULUT tahun 2010-2018, disajikapada Tabel 1.

Tabel 1. Interval Konsumsi Listrik dan PDRB Sulut 2010-2018

\begin{tabular}{|l|c|c|}
\hline & $\begin{array}{c}\text { Konsumsi Energi } \\
\text { Listrik SULUT } \\
\text { (Gwh) }\end{array}$ & $\begin{array}{c}\text { PDRB SULUT } \\
\text { (Juta rupiah) }\end{array}$ \\
\hline Maksimum & 817 & 12.939 .427 \\
\hline Minimum & 68 & 3.603 .646 \\
\hline
\end{tabular}

Konsumsi energi listrik tertinggi di SULUT sebesar 817 Gwh pada sektor rumah tangga pada tahun 2018, sedangkan terendah $68 \mathrm{Gwh}$ pada sektor industri pada tahun 2010. PDRB SULUT yang memiliki nilai tertinggi terdapat pada sektor publik tahun 2018, sedangkan yang terendah pada sektor bisnis tahun 2010.

\subsubsection{Konsumsi Energi Sulawesi Utara}

Sistem kelistrikan di SULUT terdiri dari sistem interkoneksi $150 \mathrm{kV}$ dan $70 \mathrm{kV}$ yang disebut Sistem Minahasa dan sistem kelistrikan $20 \mathrm{kV}$ isolated. Sistem 
Dikky Malvino Maingga, Deiby Tineke Salaki, John Socrates Kekenusa

d'Cartesian: Jurnal Matematika dan Aplikasi Vol. 9, No. 2, (September 2020): 84-91

Minahasa telah tersambung dengan sistem kelistrikan Provinsi Gorontalo yang disebut Sistem Sulawesi Bagian Utara (Sulbagut). Sistem Minahasa melayani Kota dan Kabupaten se Provinsi Sulawesi Utara yang berada di daratan. Sistem kelistrikan $20 \mathrm{kV}$ melayani kota/daerah yang berlokasi di Kepulauan yaitu Kabupaten Kepulauan Sitaro, Kepulauan Sangihe, dan Kepulauan Talaud, termasuk sistem isolated pulau terluar Indonesia yaitu Pulau Miangas, Marore, dan Marampit.

Beberapa pulau kecil di sekitar Kota Manado, Kota Bitung dan Kabupaten Minahasa Utara juga disuplai dari sistem isolated $20 \mathrm{kV}$ meliputi pulau: Bunaken, Papusungan, Manado Tua, Bangka, Talise, Nain, Mantehage, dan Gangga.

Kemampuan Sistem Sulbagut pada saat ini sekitar 327 MW yang meliputi daya mampu pembangkit di Sistem interkoneksi 150/70 kV sebesar $303 \mathrm{MW}$, dan di sistem $20 \mathrm{kV}$ sebesar 24,5 MW. Keterbatasan uap panas bumi PLTP Lahendong dan variasi musim, sehingga kemampuan PLTA seringkali menurun. Sistem kelistrikan Provinsi Sulawesi Utara saat ini dipasok oleh pusat-pusat pembangkit meliputi PLTP, PLTU, PLTA/M, dan PLTD HSD dengan total kapasitas terpasang sebesar 384 MW. Beban puncak sistem ini adalah 324 MW. Cadangan sistem ini di bawah 10\% (di bawah cadangan yang wajar) sehingga masih sering terjadi pemadaman.

Mengacu pada pertumbuhan beban puncak, maka terlihat jelas kebutuhan akan energi listrik juga ikut meningkat. Peningkatan ini juga dipengaruhi oleh jumlah penduduk yang terus meningkat dari tahun ke tahun. Faktor lain yang juga mempengaruhi pertumbuhan konsumsi energi listrik ialah pertumbuhan ekonomi rakyat.

Konsumsi energi tahun 2010-2018 per sektor pelanggan ditunjukkan pada Tabel 2, dan dalam bentuk grafik disajikan dalam Gambar 1. Dari data yang ada terlihat bahwa konsumsi energi listrik di SULUT mengalami peningkatan di setiap tahunnya.

Tabel 2. Konsumsi Energi Listrik Sulawesi Utara 2010-2018(Gwh)

\begin{tabular}{|l|c|c|c|c|c|c|c|c|c|}
\hline \multirow{2}{*}{$\begin{array}{l}\text { Kelompok } \\
\text { Pelanggan }\end{array}$} & \multicolumn{10}{|c|}{ TAHUN } \\
\cline { 2 - 10 } & 2010 & 2011 & 2012 & 2013 & 2014 & 2015 & 2016 & 2017 & 2018 \\
\hline $\begin{array}{l}\text { Rumah } \\
\text { Tangga }\end{array}$ & 508 & 567 & 600 & 668 & 701 & 734 & 749 & 773 & 817 \\
\hline Industri & 68 & 73 & 85 & 105 & 108 & 119 & 156 & 222 & 273 \\
\hline Bisnis & 214 & 254 & 302 & 309 & 310 & 315 & 354 & 399 & 432 \\
\hline Publik & 73 & 93 & 101 & 112 & 122 & 136 & 142 & 152 & 163 \\
\hline
\end{tabular}

KONSUMSI TENAGA LISTRIK SULUT 2010-2018 (GWH)

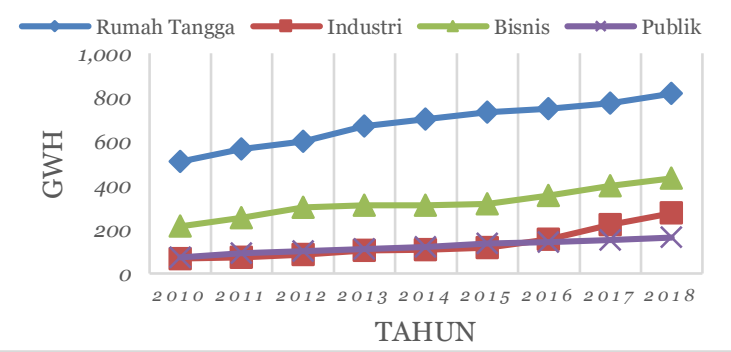

Gambar 1. Grafik Konsumsi Energi Listrik SULUT

\subsubsection{Konsumsi Energi Sulawesi Utara}

Data PDRB SULUT sesuai harga konstan (juta rupiah) selama tahun 2010-2018 yang telah diklasifikasikan ke dalam 4 sektor pelanggan, yakni sektor rumah tangga, bisnis, industri, dan publik. disajikan pada Tabel 3 dan Gambar 2. Berdasarkan sajian tersebut terlihat bahwa PDRB SULUT sepanjang tahun 2010-2018 mengalami peningkatan di setiap tahunnya.

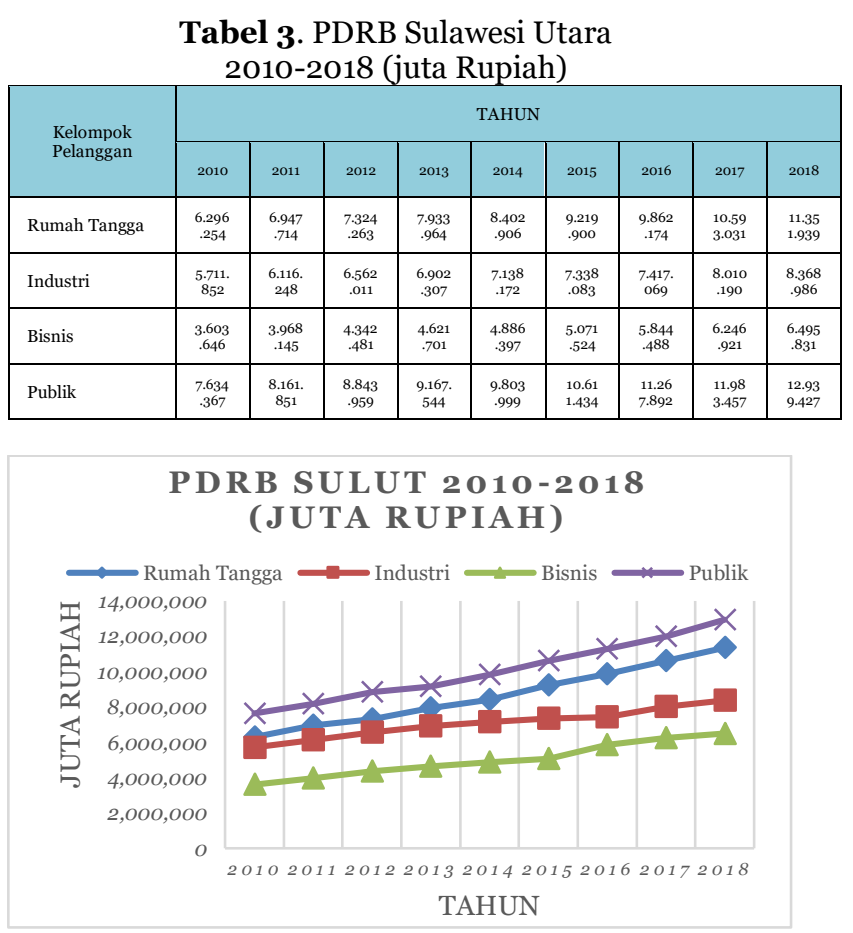

Gambar 2. Grafik Perkembangan PDRB Sulut

\subsection{Identifikasi Model}

\subsubsection{Estimasi Model Regresi Data Panel}

Pemodelan yang dilakukan dalam penelitian ini menggunakan data konsumsi energi di SULUT sebagai variabel dependen, dan data PDRB sebagai variabel independen.

\subsubsection{Common Effect Model (CEM)}

Hasil analisis regresi data panel dengan model CEM disajikan pada Tabel 4. Hasil analisisnya disajikan pada

Tabel 4. Hasil Regresi Data Panel Model CEM

\begin{tabular}{|l|c|c|}
\hline Variabel & Koefisien & P-value \\
\hline PDRB & 0,0000143 & 0,4182 \\
\hline Konstanta & 204,1956 & 0,1533 \\
\hline
\end{tabular}

Persamaan regresi ialah sebagai berikut:

$$
\hat{y}_{i t}=204,1956+0,0000143 x_{i t}
$$

\subsubsection{Fixed Effect Model (FEM)}

Hasil analisis regresi data panel dengan model FEM disajikan pada Tabel 5 dan Tabel 6.

Tabel 5. Hasil Regresi Data Panel Model FEM

\begin{tabular}{|l|c|c|}
\hline Variabel & Koefisien & P-value \\
\hline PDRB & 0,0000437 & 0,0000 \\
\hline Konstanta & $-21,92440$ & 0,5703 \\
\hline
\end{tabular}

Persamaan regresinya, seperti berikut: 
Analisis Regresi Data Panel Untuk Peramalan Konsumsi Energi Listrik di Sulawesi

d'Cartesian: Jurnal Matematika dan Aplikasi Vol. 9, No. 2, (September 2020): 84-91

$$
\hat{y}_{i t}=\hat{\beta}_{i}+0,0000437 x_{i t}
$$

Besaran nilai intersep $\hat{\beta}_{i}$ berbeda-beda untuk setiap sector, seperti yang tersaji dalampada Tabel 6 .

Tabel 6. Estimasi intersep $\hat{\beta}_{i}$ model FEM

\begin{tabular}{|c|l|c|}
\hline $\begin{array}{c}\text { Indeks } \\
\text { (i) }\end{array}$ & \multicolumn{1}{|c|}{ Sektor } & $\widehat{\boldsymbol{\beta}}_{\boldsymbol{i}}$ \\
\hline 1 & Rumah Tangga & 345,31 \\
\hline 2 & Industri & $-130,27$ \\
\hline 3 & Bisnis & 146,05 \\
\hline 4 & Publik & $-273,39$ \\
\hline
\end{tabular}

\subsubsection{Random Effect Model (REM)}

Hasil analisis regresi data panel dengan model REM disajikan pada Tabel 7 dan Tabel 8.

Tabel 7. Hasil Regresi Data Panel REM

\begin{tabular}{|l|c|c|}
\hline Variabel & Koefisien & P-value \\
\hline PDRB & 0,0000435 & 0,0000 \\
\hline Konstanta & $-20,80312$ & 0,8996 \\
\hline
\end{tabular}

Persamaan regresinya ialah sebagai berikut:

$$
\hat{y}_{i t}=\hat{\beta}_{i}+0,0000435 x_{i t}
$$

Besaran nilai intersep $\hat{\beta}_{i}$ berbeda-beda untuk setiap sector, seperti yang tersaji dalam Tabel 8.

Tabel 8. Estimasi intersep $\hat{\beta}_{i}$ model REM

\begin{tabular}{|c|l|c|}
\hline $\begin{array}{c}\text { Indeks } \\
\text { (i) }\end{array}$ & \multicolumn{1}{|c|}{ Sektor } & $\widehat{\boldsymbol{\beta}}_{\boldsymbol{i}}$ \\
\hline 1 & Rumah Tangga & 343,79 \\
\hline 2 & Industri & $-131,24$ \\
\hline 3 & Bisnis & $\mathbf{1 4 4 , 3 4}$ \\
\hline 4 & Publik & $-273,68$ \\
\hline
\end{tabular}

\subsubsection{Pemilihan Model Estimasi Regresi Data Panel}

4.2.2.1. Uji Chow

Uji Chow digunakan untuk menentukan apakah model FEM atau model CEM yang paling tepat digunakan untuk mengestimasi data panel. Hasil uji Chow disajikan pada Tabel 9.

Tabel 9. Hasil Uji Chow
\begin{tabular}{|l|c|c|c|}
\hline $\begin{array}{l}\text { Uji } \\
\text { Pengaruh }\end{array}$ & Fhitung $_{\text {Uji F }}$ & F tabel & $\begin{array}{c}\text { P- } \\
\text { value }\end{array}$ \\
\hline Uji & 420,763956 & 10,13 & 0,0000 \\
\hline
\end{tabular}

Dari Tabel 9 terlihat bahwa nilai $\mathrm{p}<0,05$, ini menunjukkan bahwa untuk mengestimasi data panel, model FEM yang tepat digunakan dibandingkan dengan model CEM.

\subsubsection{Uji Hausman}

Model FEM dibandingkan lagi dengan model REM, menggunakan uji Hausman. Hasil uji Hausman disajikan pada Tabel 10.

Tabel 1o. Hasil Uji Hausman

\begin{tabular}{|l|c|c|c|}
\hline Uji Pengaruh & $\chi^{\mathbf{2}_{\text {hitung }}}$ & $\boldsymbol{\chi}^{\mathbf{2}}{ }_{\text {tabel }}$ & $\begin{array}{c}\text { P- } \\
\text { value }\end{array}$ \\
\hline Uji Chi-Square & 0,267898 & 49,8 & 0,6047 \\
\hline
\end{tabular}

Hasil uji Hausman menunjukkan nilai p > 0,05, dengan demikian $H_{0}$ diterima. Ini berarti bahwa model REM yang lebih tepat digunakan untuk mengestimasi data panel.

Dalam Ekonometrika terdapat beberapa pilihan mendasar untuk menentukan model FEM atau model REM yang akan digunakan. Pendekatan model REM memiliki syarat bahwa number of unit cross-section harus lebih besar daripada number of time series. Dalam penelitian ini, jumlah data time-series $t$, lebih besar daripada jumlah unit cross-section N. Dengan demikian, model REM tidak memenuhi syarat untuk digunakan, sehingga yang lebih pantas ialah model FEM [13].

\subsubsection{Analisis Hasil Estimasi Fixed Effect}

Model FEM untuk pengaruh variabel PDRB Sulawesi Utara terhadap konsumsi energi listrik, dinyatakan dalam bentuk persamaan:

$$
\text { Konsumsi Energi Listrik } k_{i t}=\hat{\beta}_{i}+0,0000437 P D R B_{i t}+\varepsilon_{i t}
$$

Besaran nilai intersep $\hat{\beta}_{i}$ berbeda-beda untuk setiap sektor seperti yang tersaji pada Tabel 6 .

Tabel 6. Estimasi intersep $\hat{\beta}_{i}$ model FEM

\begin{tabular}{|c|l|c|}
\hline $\begin{array}{c}\text { Indeks } \\
\text { (i) }\end{array}$ & \multicolumn{1}{|c|}{ Sektor } & $\widehat{\boldsymbol{\beta}}_{\boldsymbol{i}}$ \\
\hline 1 & Rumah Tangga & 345,31 \\
\hline 2 & Industri & $-130,27$ \\
\hline 3 & Bisnis & 146,05 \\
\hline 4 & Publik & $-273,39$ \\
\hline
\end{tabular}

\subsubsection{Uji Asumsi Regresi Data Panel}

Uji asumsi klasik yang digunakan dalam regresi data panel adalah normalitas, heteroskedastisitas, dan multikolinieritas. Hasil uji asumsi klasik dalam penelitian ini ialah sebagai berikut:

\subsubsection{Uji Normalitas}

Hasil uji normalitas data ditampilkan pada Gambar 3

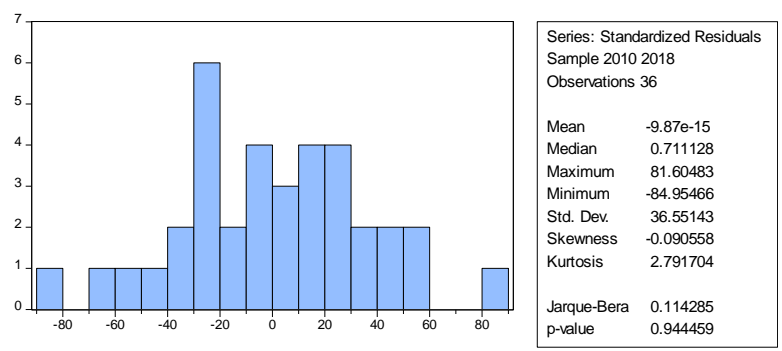

Gambar 3. Hasil Uji Normalitas data

Dari Gambar 3 terlihat bahwa nilai $\mathrm{p}>0,05$, yang menunjukkan bahwa data berdistribusi normal.

\subsubsection{Uji Heteroskedastisitas} Tabel 11

Hasil uji heteroskedastisitas ditampilkan pada

Tabel 11. Hasil Uji Heteroskedastisitas

\begin{tabular}{|l|c|c|}
\hline Variabel & P-value & Nilai $\boldsymbol{\alpha}$ \\
\hline PDRB & 0,0728 & 0,05 \\
\hline
\end{tabular}

Hasil uji menunjukkan bahwa $\mathrm{p}>0,05$, yang berarti tidak terjadi heteroskedastisitas. Pada penelitian ini 
Dikky Malvino Maingga, Deiby Tineke Salaki, John Socrates Kekenusa

d'Cartesian: Jurnal Matematika dan Aplikasi Vol. 9, No. 2, (September 2020): 84-91

tidak dilakukan uji multikolinieritas, karena hanya terdapat satu variabel independent.

\subsubsection{Pemeriksaan Persamaan Regresi 4.2.5.1. Uji Simultan (Uji F)}

Uji F-Statistik digunakan untuk mengetahui seberapa besar pengaruh PDRB Sulawesi Utara terhadap Konsumsi Energi Sulawesi Utara selama periode 2010 sampai 2018 secara simultan atau bersama-sama. Hasil uji F disajikan pada Tabel 12.

Tabel 12. Hasil Uji F

\begin{tabular}{|c|c|c|}
\hline $\mathbf{F}_{\text {hitung }}$ & $\mathbf{F}_{\text {tabel }}$ & P-value \\
\hline 321,9597 & 4,113165 & 0,0000 \\
\hline
\end{tabular}

Hasil uji $\mathrm{F}$ diperole nilai $\mathrm{p}<0,05$, yang berarti PDRB Sulawesi Utara memberi pengaruh signifikan terhadap Konsumsi Energi Sulawesi Utara periode 2010 sampai 2018.

\subsubsection{Koefisien Determinasi $\left(R^{2}\right)$}

Koefisien determinasi pada regresi data panel digunakan untuk mengetahui seberapa besar variabel independen dapat menjelaskan variabel dependen. Nilai koefisien determinasi dalam penelitian ini ditampilkan pada Tabel 13 .

Tabel 13. Nilai Koefisien Determinasi

\begin{tabular}{|l|c|}
\hline $\boldsymbol{R}^{\mathbf{2}}$ & 0,976494 \\
\hline Adjusted $\boldsymbol{R}^{\mathbf{2}}$ & 0,973462 \\
\hline
\end{tabular}

Nilai $\mathrm{R}^{2}$ sebesar 0,976494 (97,64\%), berarti bahwa variabel konsumsi energi listrik di Sulut, 97,64\% dapat dijelaskan oleh variable PDRB Sulut, sedangkan sisanya sebesar $2,36 \%$ dipengaruhi faktor lain selain model regresi tersebut.

\subsubsection{Peramalan Konsumsi Energi Listrik Sulawesi Utara}

\subsubsection{Peramalan PDRB Sulut dengan Analisis} Trend

Peramalan variabel PDRB Sulut untuk masingmasing sektor dilakukan dengan menggunakan analisis trend: linier, kuadratik, dan eksponensial. Pemilihan trend yang paling baik didasarkan pada nilai MAPE, MAD, dan MSD yang paling kecil.

Tabel 14. Analisis Tren Linear

\begin{tabular}{|l|c|c|c|}
\hline \multirow{2}{*}{ Sektor } & \multicolumn{3}{|c|}{ Tren Linear } \\
\cline { 2 - 4 } & MAPE & MAD & MSD \\
\hline $\begin{array}{l}\text { Rumah } \\
\text { Tangga }\end{array}$ & 1,5 & $1,2 \mathrm{E}+05$ & $1,9 \mathrm{E}+10$ \\
\hline Industri & 1,4 & $9,7 \mathrm{E}+04$ & $1,5 \mathrm{E}+10$ \\
\hline Bisnis & 2,0 & $9,9 \mathrm{E}+04$ & $1,7 \mathrm{E}+10$ \\
\hline Publik & 1,5 & $1,4 \mathrm{E}+05$ & $2,9 \mathrm{E}+10$ \\
\hline
\end{tabular}

Tabel 15. Analisis Tren Kuadratik

\begin{tabular}{|l|c|c|c|}
\hline \multirow{2}{*}{ Sektor } & \multicolumn{3}{|c|}{ Tren Kuadratik } \\
\cline { 2 - 4 } & MAPE & MAD & MSD \\
\hline $\begin{array}{l}\text { Rumah } \\
\text { Tangga }\end{array}$ & 1,0 & $4,7 \mathrm{E}+04$ & $3,8 \mathrm{E}+09$ \\
\hline Industri & 1,3 & $9,4 \mathrm{E}+04$ & $1,4 \mathrm{E}+10$ \\
\hline Bisnis & 1,8 & $9,2 \mathrm{E}+04$ & $1,2 \mathrm{E}+10$ \\
\hline
\end{tabular}

$$
\begin{array}{|l|l|l|l|}
\text { Publik } & 1,0 & 6,4 \mathrm{E}+04 & 6,0 \mathrm{E}+09 \\
\hline
\end{array}
$$

Tabel 16. Analisis Tren Eksponensial

\begin{tabular}{|l|c|c|c|}
\hline \multirow{2}{*}{ Sektor } & \multicolumn{3}{|c|}{ Tren Eksponensial } \\
\cline { 2 - 4 } & MAPE & MAD & MSD \\
\hline $\begin{array}{l}\text { Rumah } \\
\text { Tangga }\end{array}$ & 1,0 & $5,1 \mathrm{E}+04$ & $3,9 \mathrm{E}+09$ \\
\hline Industri & 1,5 & $1,0 \mathrm{E}+05$ & $1,8 \mathrm{E}+10$ \\
\hline Bisnis & 1,8 & $9,5 \mathrm{E}+04$ & $1,2 \mathrm{E}+10$ \\
\hline Publik & 1,0 & $6,4 \mathrm{E}+04$ & $6,5 \mathrm{E}+09$ \\
\hline
\end{tabular}

Berdasarkan hasil analisis untuk semua sektor, trend kuadratik sebagai trend terbaik, karena memiliki nilai MAPE, MAD, dan MSD yang paling kecil.

Dengan demikian, forecasting atau peramalan variabel PDRB tahun 2019 dan 2020 untuk masing sector, menggunakan persamaan dengan trend kuadratik. Model persamaan kuadratik yang digunakan untuk peramalan, dan hasil peramalan variabel PDRB Sulut tahun 2019 dan 2020 untuk setiap sektornya disajikan dalam Tabel 17.

Tabel 17. Model Persamaan Kuadratik dan Hasil Peramalan Variabel PDRB Sulut Tahun 2019 dan 2020

\begin{tabular}{|c|c|c|c|}
\hline \multirow{2}{*}{ Sektor } & \multirow{2}{*}{$\begin{array}{l}\text { Model Tren } \\
\text { Kuadratik }\end{array}$} & \multicolumn{2}{|c|}{ PDRB (Juta rupiah) } \\
\hline & & 2019 & 2020 \\
\hline $\begin{array}{l}\text { Rumah } \\
\text { Tangga }\end{array}$ & $\begin{array}{l}X_{t}=5924671+411387 t \\
+21395 t^{2}\end{array}$ & 12.178 .041 & 13.038 .723 \\
\hline Industri & $\begin{array}{l}X_{t}=5454625+345853 t \\
-3825 t^{2}\end{array}$ & 8.530 .655 & 8.796 .183 \\
\hline Bisnis & $\begin{array}{l}X_{t}=3391453+253035 t \\
+11128 t^{2}\end{array}$ & 7.034 .603 & $7 \cdot 521.326$ \\
\hline Publik & $\begin{array}{l}X_{t}=7271456+391324 t \\
+25829 t^{2}\end{array}$ & 13.767 .596 & 14.701 .329 \\
\hline
\end{tabular}

\subsubsection{Peramalan Konsumsi Energi Listrik Sulut dengan Regresi Data Panel}

Untuk mendapatkan nilai prediksi variabel konsumsi energi listrik di Sulawesi Utara pada tahun 2019 dan 2020, dilakukan dengan mensubstitusi hasil peramalan variabel PDRB Sulut pada Tabel 17, ke dalam model FEM yang telah diperoleh. Hasil peramalan konsumsi energi listrik di Sulut untuk tahun 2019 dan 2020 disajikan pada Tabel 18.

Tabel 18. Peramalan Konsumsi Energi Listrik

\begin{tabular}{|c|c|c|c|}
\hline \multirow{2}{*}{ Sektor } & \multirow{2}{*}{ Model Regresi Data Panel } & \multicolumn{2}{|c|}{$\begin{array}{l}\text { Konsumsi } \\
\text { Energi }\end{array}$} \\
\hline & & 2019 & 2020 \\
\hline $\begin{array}{l}\text { Rumah } \\
\text { Tangga }\end{array}$ & $\begin{array}{l}\hat{y}_{t}=323,3856-21,9244+ \\
0,0000437 x_{t}\end{array}$ & 833 & 871 \\
\hline Industri & $\begin{array}{l}\hat{y}_{t}=-152,1986-21,9244+ \\
0,0000437 x_{t}\end{array}$ & 198 & 210 \\
\hline Bisnis & $\begin{array}{l}\hat{y}_{t}=124,130510516-21,9244+ \\
0,0000437 x_{t}\end{array}$ & 409 & 431 \\
\hline Publik & $\begin{array}{l}\hat{y}_{t}=-295,3175-21,9244+ \\
0,0000437 x_{t}\end{array}$ & 284 & 325 \\
\hline
\end{tabular}

Pada Tabel 18, terlihat bahwa konsumsi energi di SULUT pada tahun 2019 dan 2020 meningkat untuk sektor rumah tangga, dan publik. Untuk sektor industri dan bisnis, mengalami penurunan pada tahun 2019, tetapi meningkat kembali pada tahun 2020.

Hasil penelitian ini sejalan dengan landasan teori bahwa salah satu karakteristik peningkatan konsumsi energi listrik, akibat tingginya PDRB di suatu wilayah. Artinya, dengan meningkatnya PDRB akan merubah pola kosumsi termasuk tingkat daya konsumsi energi listrik untuk setiap sektor. Dengan demikian, 
peningkatan PDRB di SULUT, akan meningkatkan konsumsi energi listrik.

\section{KESIMPULAN}

Berdasarkan hasil analisis dan pembahasan, diperoleh beberapa kesimpulan sebagai berikut:

1. Model regresi data panel terbaik untuk data konsumsi energi listrik di Sulawesi Utara sebagai variabel dependen dan data Produk Domestik Regionak Bruto Sulawesi Utara sebagai variabel independen, ialah model FEM dengan efek individu, dengan persamaan sebagai berikut:

Konsumsi Energi Listrik $k_{i t}=\hat{\beta}_{i}+0,0000437 P D R B_{i t}$

2. Sebesar 97,64\% konsumsi energi listrik di SULUT dapat dijelaskan oleh variabel PDRB SULUT.

3. Setiap pertambahan PDRB Sulawesi Utara sebesar satu juta rupiah, akan menaikkan total konsumsi energi listrik akhir sebesar $43,7 \mathrm{kWh}$.

\section{REFERENSI}

[1] Titaley, H.D. 2015. Penggunaan Model Regresi untuk Memprediksi Arus Lalu Lintas Laut yang Berdampak pada Kebutuhan Fasilitas Pelabuhan (Studi Kasus : Pelabuhan Yos Sudarso Ambon). d'Cartesian jurnal matematika dan aplikasi. 4(2): 204-209.

[2] Baltagi, B.H. 2003. A Companion to Theoritical Econometrics. Blackwell Publishing Ltd.

[3] Winarno, W. W. 2007. Eviews: Analisis ekonometrika dan statistika. Yogyakarta: Sekolah Tinggi Ilmu Manajemen YKPN.

[4] Firdaus, M. 2011. Aplikasi Ekonometrika untuk Data Panel dan Time Series. Bogor: IPB Press.

[5] Baltagi, B. H. 2008. Econometrics ( $4^{\text {th }}$ ed). Verlag Berlin Heidelberg: Springer.

[6] Srihardianti, M., Mustafid., dan Prahutama, A. 2016. Metode Regresi Data Panel Untuk Peramalan Konsumsi Energi Di Indonesia. Jurnal Gaussian. 5(3): $475-485$.

[7] Pangestika, M. 2017. Analisis Regresi Data Panel Terhadap Faktor-faktor yang Mempengaruhi Indeks Pembangunan Manusia di D.I. Yogyakarta. Skripsi. Jurusan Statistika Fakultas Matematika dan Ilmu Pengetahuan Alam Universitas Islam Indonesia.

[8] Gujarati, Damodar. 1993. Ekonometrika Dasar. Cetakan ketiga. Sumarno Zain [penerjemah] Jakarta: Erlangga.

[9] Lawendatu, J.R., Kekenusa, J.S., dan Hatidja, D. 2014. Regresi Linier Berganda Untuk Menganalisis Pendapatan Petani Pala. d'Cartesian jurnal matematika dan aplikasi. 3(1): 66-72.

[10] Pangestika, S. 2015. Analisis Estimasi Model Regresi Data Panel dengan Pendekatan Common Effect Model (CEM), Fixed Effect Model (FEM), dan Random Effect Model (REM). Skripsi. Jurusan Matematika Fakultas Matematika dan Ilmu Pengetahuan Alam Universitas Negeri Semarang.

[11] Gujarati, D. N. 2004. Basic Econometrics ( $4^{\text {th }}$ ed). New York: The McGraw-Hill Companies.

[12] Nachrowi, D. N. \& H. Usman. 2006. Pendekatan Populer dan Praktis Ekonometrika untuk Analisis Ekonomi dan Keuangan. Jakarta: Lembaga Penerbit FE UI.

[13] Gujarati, D. N. 2006. Essentials of Econometrics (3 $3^{\text {rd }}$ ed). Translated by Mulyadi, J. A. dkk. 2007. Jakarta: Erlangga.
Dikky Malvino Maingga (dikkymalvino@gmail.com)

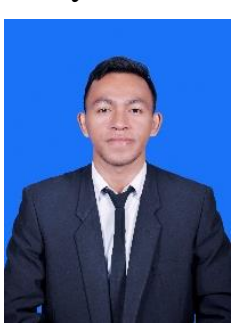

Lahir di Banggai, Sulawesi Tengah pada tanggal o9 Februari 1999. Menempuh pendidikan tinggi Jurusan Matematika, FMIPA, Universitas Sam Ratulangi Manado. Tahun 2020 adalah tahun terakhir ia menempuh studi. Makalah ini merupakan hasil penelitian skripsinya yang dipublikasikan.

John Socrates Kekenusa (johnskekeunsa@unsrat.ac.id)

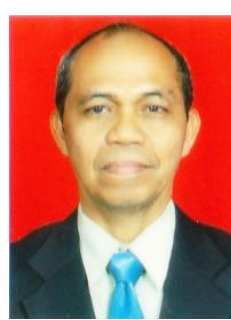
Lahir di Tahuna tanggal 24 Agustus 1958. Gelar sarjana perikanan diperoleh tahun 1982 di Universitas Sam Ratulangi. Tahun 1988 menyelesaikan studi S2, Bidang Statistika Terapan di IPB Bogor. Tahun 2006 menyelesaikan studi $\mathrm{S}_{3}$ dalam bidang MIPA/Statistika di Universitas Airlangga. Sejak tahun 2007 diangkat sebagai Guru Besar Statistika, di Jurusan Matematika F-MIPA Unsrat Manado.

Deiby Tineke Salaki (deibyts.mat@unsrat.ac.id)

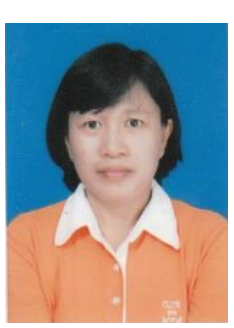
Lahir di Minahasa Selatan tanggal 17 Desember 1972. Gelar sarjana Matematika diperoleh tahun 1998 di Jurusan Matematika IPB Bogor. Tahun 2009 menyelesaikan studi S2, di Jurusan Matematika IPB Bogor. Tahun 2018 menyelesaikan studi S3 pada bidang Matematika di IPB Bogor. Saat ini menjadi pengajar tetap di Jurusan Matematika F-MIPA

Unsrat Manado. 